\title{
Electrochemical Sensor Based on the Clay- Carbone Paste Electrode Modified by Bacteria-Polymer for Elimination of Phenol
}

\author{
R Maallah*, MA Smaini, C Laghlimi, J El Mastour and A Chtaini \\ Molecular Electrochemistry and Inorganic Materials Team, Sultan Moulay Slimane University, Morocco
}

*Corresponding author: R Maallah, Molecular Electrochemistry and Inorganic Materials Team, Sultan Moulay Slimane University, Morocco.

To Cite This Article: R Maallah. Electrochemical Sensor Based on the Clay-Carbone Paste Electrode Modified by Bacteria-Polymer for Elimination of Phenol. Am J Biomed Sci \& Res. 2018 - 4(5). AJBSR.MS.ID.000839. DOI: 10.34297/AJBSR.2019.04.000839

Received: 眥 August 05, 2019; Published: 眥 August 22, 2019

\begin{abstract}
A Cyclic voltammetry (VC), Square Wave Voltammetry and Impedance Spectroscopie methods for the determination of trace amounts of phenol at bacteria-polymer-Clay-CPE bioelectrode is proposed. The results showed that the bacteria-polymer-Clay-CPE exhibited excellent electro catalytic activity to phenol. This electrochemical biosensor shows an excellent performance for detecting phenol.
\end{abstract}

Keywords: Modified electrodes; Cyclic voltammetry; Clay; impedance spectroscopy; Bacteria; Phenol

\section{Introduction}

Phenol and related compounds are widely used in industry for the manufacture of a wide variety of aromatic compounds, including rubber, fertilizers, paints, drug preparations, petroleum and agricultural industries [1,2]. Phenol is considered carcinogenic and exposure to phenol causes several symptoms such as convulsions, dizziness and irregular breathing [1,3]. Phenol is one of 129 compound chemicals considered important pollutants listed by the Environmental Protection Agency (EPA) [4,5]. Due to severe legislation, prohibit the release of toxic products into the environment. Current research has focused on the development of a simple, cost-effective, fast and reliable technology that can be used for the immediate detection of heavy metals and toxic products in the environment. In this context, a technology seems to fully correspond to the requirements necessary for sustainable development and the preservation of the ecosystem: "bio electrochemistry". This discipline can be defined as a science involving the principles of electrochemistry associated with the field of living. Here we will focus on the electrochemistry / bacteria coupling. Indeed, the conversion of the catalytic activity of a bacterium into an electric current has paved the way for the development of various and varied bioelectrodes. Their fields of application are currently numerous and particularly in fields such as energy (biopiles) and analytical applications (bacterial biosensors) [6,7].
With regard to electro-analytical techniques, procedures involving the oxidation of phenol on solid electrodes [8,9] have been reported. In addition, chemically modified carbon paste electrodes have proved very useful for analytical applications [10]. In previous work [11,12], the electrochemical oxidation of phenol has been studied. We present a simple and sensitive method of determining these compounds based on their reaction. The purpose of the work presented here was to study the electrochemical properties of phenol on the bacterial-polymer-clay modified carbon paste electrode as well as the electrochemical characterization of electrodes by the cyclic voltammetric technique, Square Wave Voltammetry and Impedance Spectroscopie.

\section{Experimental}

\section{Apparatus and Software}

Voltammetric experiments were performed using a voltalab potentiostat (model PGSTAT 100, Eco Chemie B.V., Utrecht, The Netherlands) driven by the general-purpose electrochemical systems data processing software (voltalab master 4 software) run under windows 2007. The three-electrode system consisted of a chemically modified carbon paste electrode as the working electrode a saturated calomel electrode (SCE) serving as reference electrode, and platinum as an auxiliary electrode. 


\section{Electrodes}

Modified electrodes were prepared by mixing a carbon powder and the desired weight of clay. The body of the working electrode for voltammetric experiments was a PTFE cylinder that was tightly Procedure for Immobilization of Bacteria in a Polymer Film

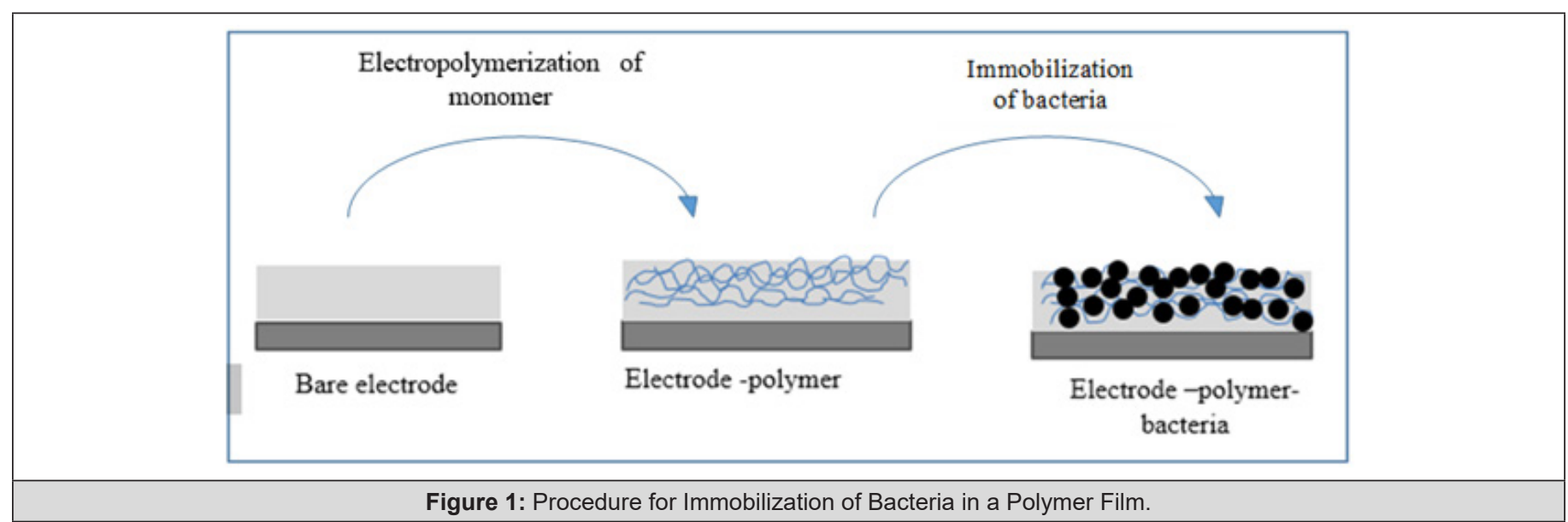

The modified electrodes were immersed in a cell $100 \mathrm{ml}$ of the distilled water, $0.1 \mathrm{M} \mathrm{NaCl}$ and the bacterial suspensions and then $0.1 \mathrm{M}$ electrolyte of $\mathrm{NaCl}$ contains $1 \mathrm{ml}$ of $\varepsilon$-caprolactone monomer, the electro polymerization is carried out by cyclic voltammetry. Then the modified electrodes were immersed in a cell $20 \mathrm{ml}$ of

\section{Results and Discussion}

\section{Surface characteristics}

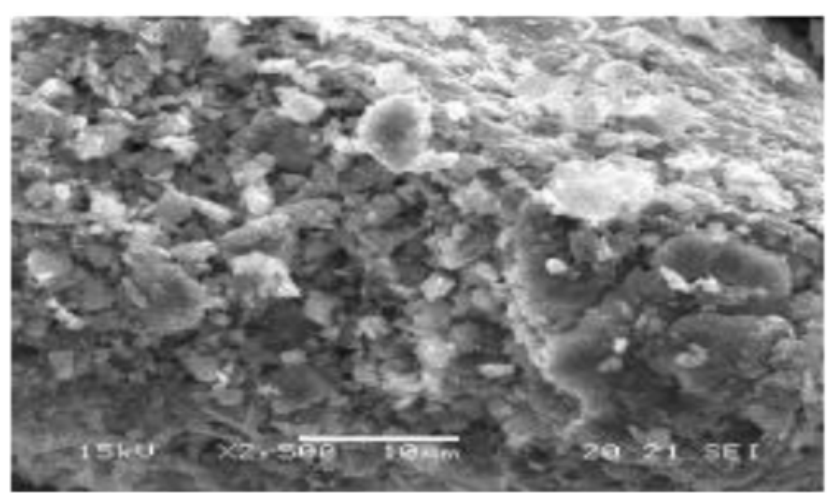

Figure 2: Scanning Electron Micrograph of Clay Paste Electrode.

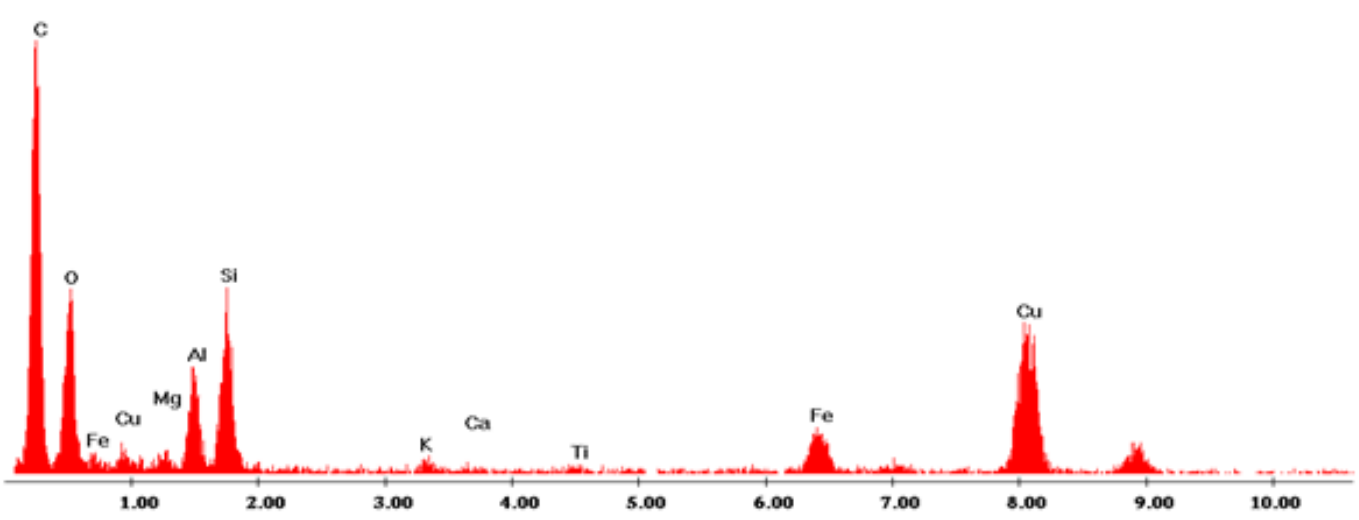

Figure 3: Chemical Composition Treated Clay. 
The morphology of the electrode surface of Clay was observed by scanning electron microscopy (Figure 2). We find that the matrix is formed by compact particles fractions between 1 and 15 $\mu \mathrm{m}$. Clay treaty has the following chemical composition given by transmission electron microscopy (TEM): $\mathrm{O}$ (22\%), Mg (5.4\%), Al (22.4\%), K (2.7\%), Ca (1\%), Ti (1.8\%) Fe (17.1\%), Si (27.8\%) and more metals order ppm (Figure 3 ). An examination of clay modified carbon paste electrode indicates some kind of agglomeration [13].

\section{Electrodeposition of Polymer and Bacteria}

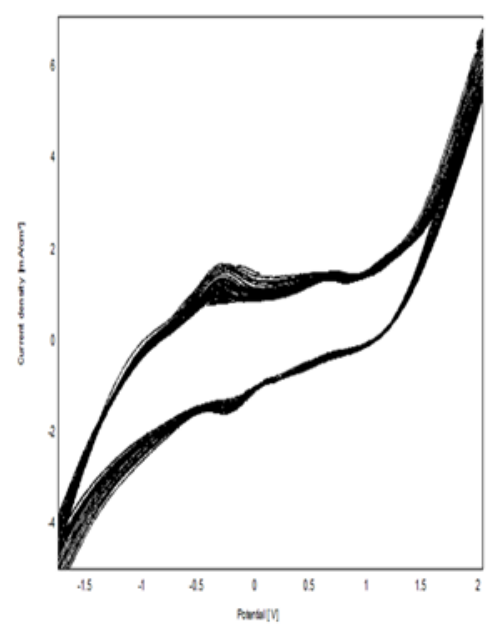

Figure 4: Cyclic Voltammograms Obtained by Clay-CPE (A) And Polymer-Clay-CPE (B) In $0.1 \mathrm{M} \mathrm{NaCl}(\mathrm{Ph}=7)$ With A Scanning Speed Of $100 \mathrm{mv} / \mathrm{s}$.

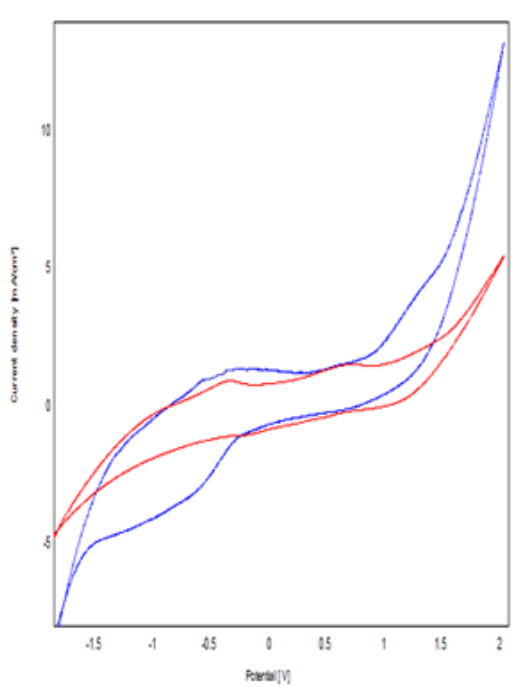

Figure 5: Cyclic Voltammograms Obtained by Clay-CPE (A) And Polymer-Clay-CPE (B) In $0.1 \mathrm{M} \mathrm{NaCl}(\mathrm{Ph}=7)$ With A Scanning Speed of $100 \mathrm{mv} / \mathrm{S}$.

Figure 4 represents the cyclic voltammograms corresponding to the polymerization of $\varepsilon$-caprolactone on the CPE-Ar electrode, recorded with a scanning speed equal to $80 \mathrm{mV} / \mathrm{S}$ in the $\mathrm{NaCl}$ solution ( $0.1 \mathrm{~mol} / \mathrm{l})$ containing $1 \mathrm{ml}$ - caprolactone in a range of potential between $-2 \mathrm{~V}$ and $2 \mathrm{~V}$. It can be seen that the presence of two anodic peaks at about $-0.35 \mathrm{~V}$ and $0.46 \mathrm{~V}$. These peaks are attributed to the oxidation of the monomer ( $\varepsilon$-caprolactone). The decrease in the intensity of the currents during the sweeps accounts for the growth of the film deposited on the surface of the electrode with the number of cycles, the densities current of the voltammograms tend to 0 indicating that the developed polymer has an insulating character [14,15] (Figure 5,6).

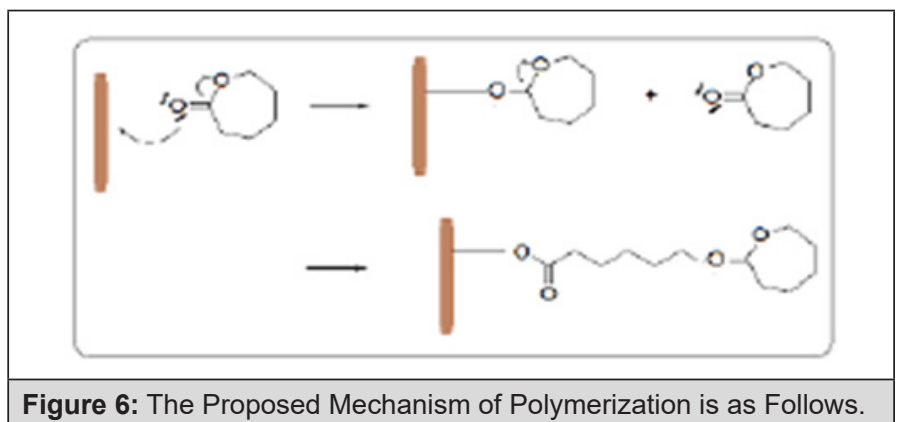

\section{Elaboration and characterization of bio- electrodes}

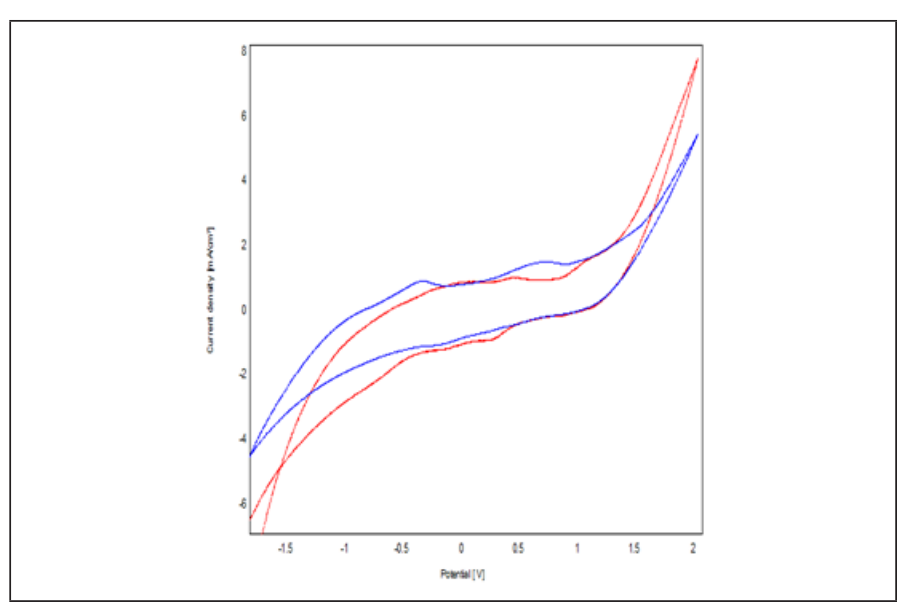

Figure 7: Cyclic Voltammograms Obtained by Polymer-Clay-CPE (A) And Bacteria-Polymer-Clay-CPE (B) In $0.1 \mathrm{M} \mathrm{NaCl}(\mathrm{Ph}=7)$ With $\mathrm{A}$ Scanning Speed Of $100 \mathrm{mv} / \mathrm{S}$.

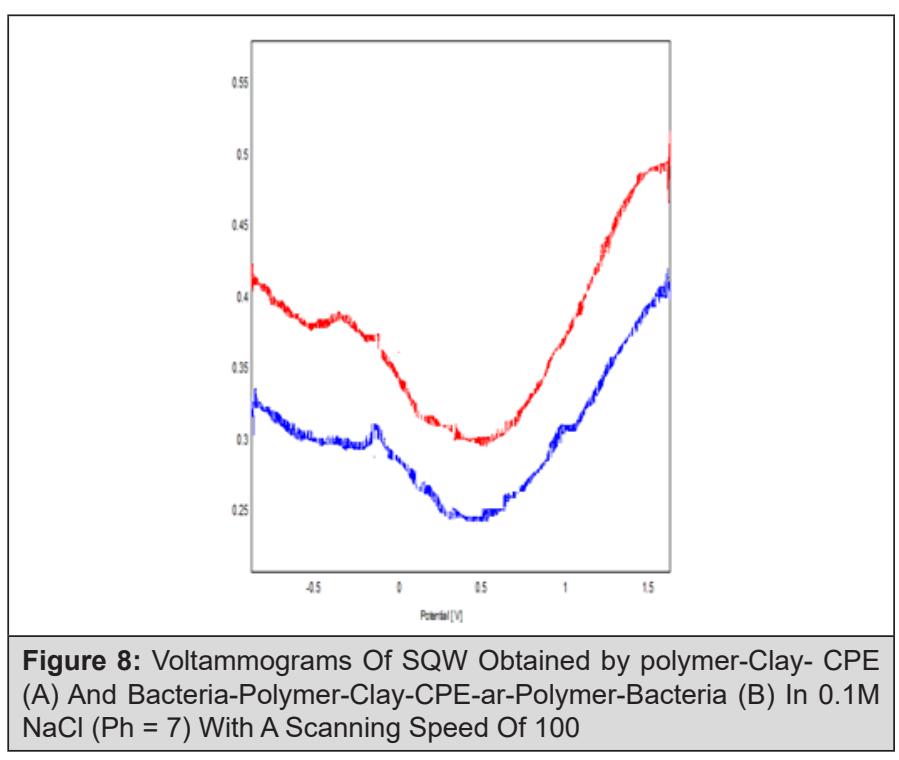

The Figures 7 \& 8 represent the cyclic voltammograms recorded respectively for the polymer-Clay - CPE and bacteria-polymer-Clay 
-CPE electrodes, in $0.1 \mathrm{M} \mathrm{NaCl}$ medium at $100 \mathrm{mV} / \mathrm{s}$. We find that the presence of bacteria in the mineral matrix leads to a relative increase in the current densities of the voltammogram in both anodic and cathodic scanning directions [16]. This effect appears clearly in square wave voltammetry. We find that the presence of bacteria in the mineral matrix leads to a relative increase in the current densities of the voltammogram in both anodic and cathodic scanning directions [16]. This effect appears clearly in square wave voltammetry.

\section{Activity of the Bacteria-Polymer- CPE Electrode with respect to the Oxidation of Phenol}

The oxidation of phenol on the bacteria-polymer-Clay-CPE electrode was studied by cyclic voltammetry (Figure 9). As we can see the recorded voltammogram, in electrolytic medium in the presence and absence of phenol. No peak is observed on the voltammogram in the absence of phenol, however, in the presence of phenol, there is the appearance of two anodic peaks corresponding to the oxidation of phenol, respectively at $0.5 \mathrm{~V}$ and $1.5 \mathrm{~V}$.

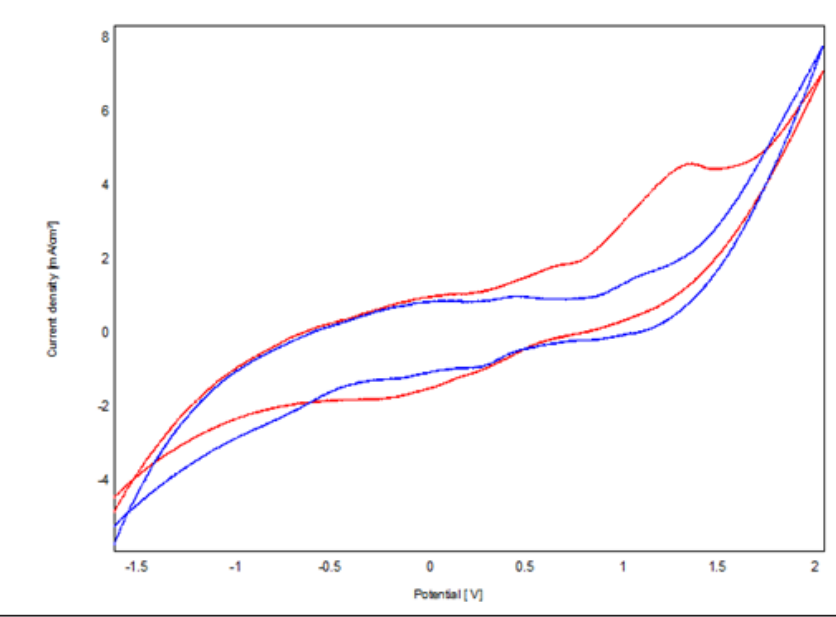

Figure 9: Cyclic Voltammograms Obtained by Bacteria-Polymer-Clay$\mathrm{CPE}$ in the Absence (a) and in the Presence (b) of $4 \mathrm{mM}$ Phenol in 0.1 $\mathrm{M} \mathrm{NaCl}(\mathrm{pH}=7)$ with a Scanning Speed of $100 \mathrm{mV} / \mathrm{S}$.

\section{Effect of Scanning Rate}

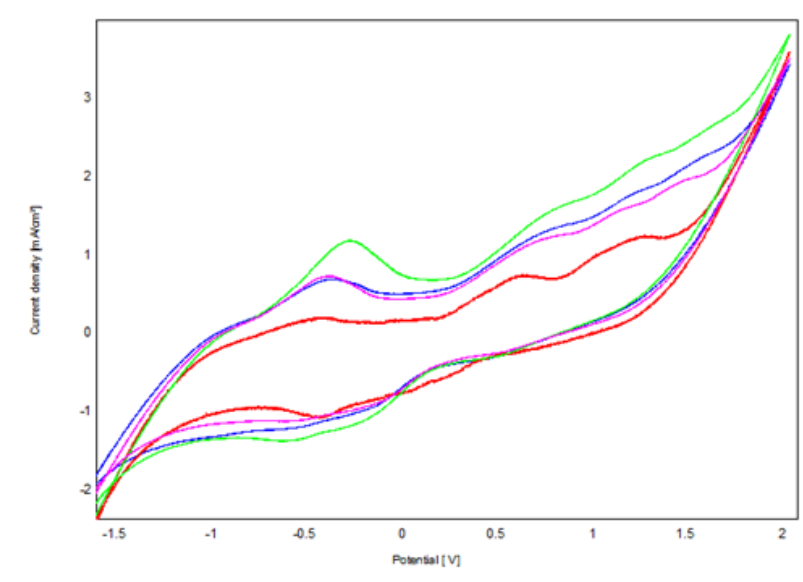

Figure 10: Voltammograms Recorded by Bacteria-Polymer-Clay -CPE with $8 \mathrm{mM}$ Phenol in $0.1 \mathrm{M} \mathrm{NaCl}(\mathrm{pH}=7)$ at Different Scan Rates from 40 to $120 \mathrm{mV} \cdot \mathrm{s}^{-1}$
The effect of the scanning rate on the intensities of the phenol oxidation peaks was studied by cyclic voltammetry, in $0.1 \mathrm{M} \mathrm{NaCl}$ ( $\mathrm{pH}=7)$, containing $8 \mathrm{mM}$ phenol, at scanning speeds included between 40 and 120 mV.s-1 (Figure 10). The current densities vary linearly with the scanning speed (Figure 11), which shows that the system is in a diffusion mode.

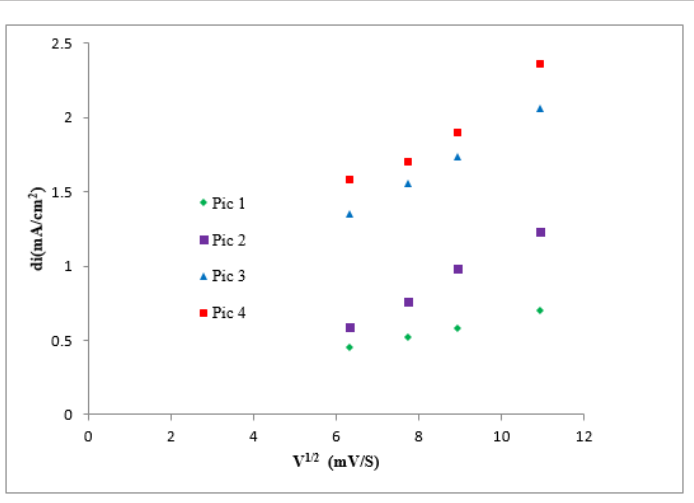

Figure 11: Effect of Sweep Rate on Phenol Oxidation Peaks

\section{Influence of Phenol Concentration}

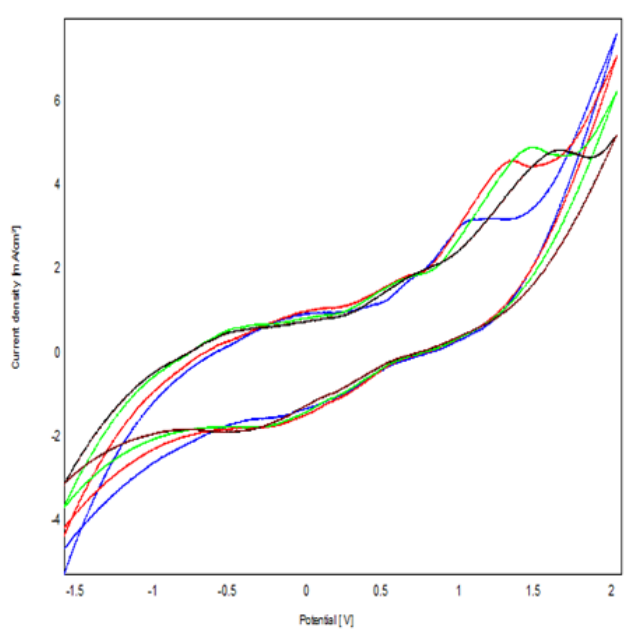

Figure 12: Cyclic Voltammograms at Different Concentrations of Phenol (from $2 \mathrm{mM}$ to $10 \mathrm{mM}$ ) in $0.1 \mathrm{M} \mathrm{NaCl}(\mathrm{pH}=7)$ on BacteriaPolymer-Clay-CPE, $\mathrm{V}=100 \mathrm{mV}^{-\mathrm{S}^{-1}}$

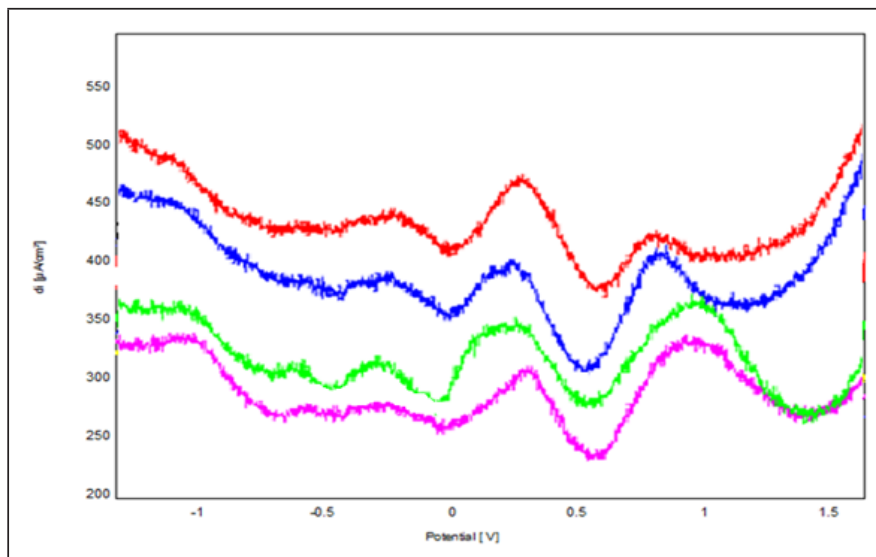

Figure 13: Voltammograms of SQW at Different Concentrations of Phenol (from $2 \mathrm{mM}$ to $10 \mathrm{mM}$ ) in $0.1 \mathrm{M} \mathrm{NaCl}(\mathrm{pH}=7)$ on BacteriaPolymer-Clay-CPE, $\mathrm{V}=100 \mathrm{mV} / \mathrm{S}$. 
The variation of anodic peak intensity as a function of phenol concentration was followed by cyclic voltammetry (Figure 12), square wave voltammetry (Figure 13), and impedance spectroscopy. We find that peak current densities increase with concentration, suggesting that the modified matrix has a large number of active sites. This result is confirmed by the impedance measurement, which shows a decrease in the electron transfer resistance [16].

\section{Evaluation of the Activity of the Bacteria-Polymer-} Clay-CPE Modified Electrode for Phenol Detection

\section{Calibration Curves}

Calibration curves were plotted from the square wave voltammetry at the surface of the polymer-Clay-CPE and bacteriapolymer-Clay-CPE electrodes (Figure 14). These experiments are carried out in the concentration range which varies between 4 and $12 \mathrm{mmol} \mathrm{l}^{-1}$. Table 1 groups together the correlation equations and the detection and quantification limits calculated for the two
polymer-Clay -CPE and bacteria-polymer-CPE electrodes. We find that the presence of bacteria improves the sensitivity of the electrodes.

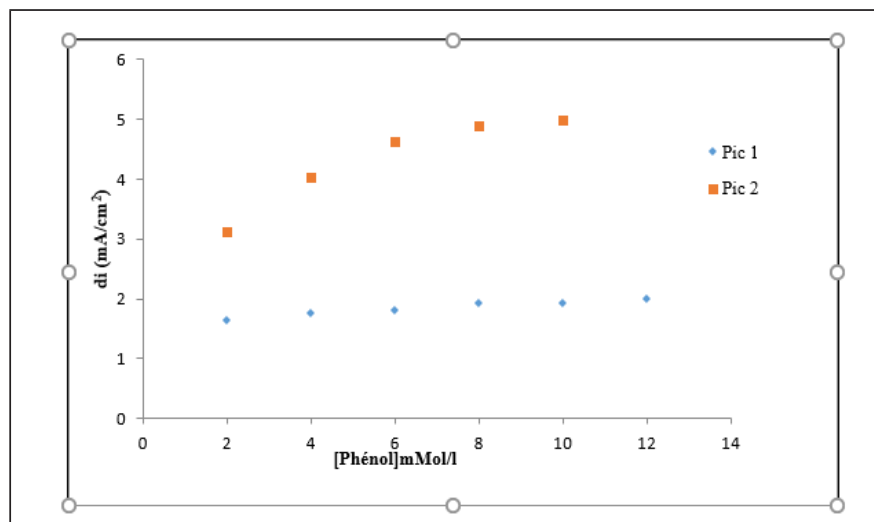

Figure 14: Effect of Concentration on the Intensity of the Phenol Oxidation Peaks for Bacteria-Polymer-Clay-CPE.

Table 1: The correlation equations and the limits of detections and quantifications calculated for the two electrodes polymer-Clay-CPE and bacteriapolymer-Clay-CPE in the presence of phenol.

\begin{tabular}{|c|c|c|c|c|}
\hline Electrode & Equation & R2 & D.L (mol. L-1) & Q.L (mol. L-1) \\
\hline Polymer-Clay-CPE+ Phenol & $\mathrm{di}=0,260 \mathrm{x}+1,431$ & $\mathrm{R}^{2}=0,853$ & $2.041 .10-5$ & $3.205 .10-4$ \\
\hline Bacteria-polymer-CPE+phenol & $\mathrm{di}=0,228 \mathrm{x}+2,963$ & $\mathrm{R}^{2}=0,882$ & $0.952 .10-6$ & $1.863 .10-5$ \\
\hline
\end{tabular}

\section{The Activity of the Immobilized Bacteria}

The activity of bacteria immobilized on the polymer-Clay-CPE electrode surface calculated for the oxidation of phenol is:

$$
\begin{aligned}
& \alpha=\left(1-\frac{\text { Ibact }}{I}\right) \times 100 \\
& \alpha=(1-(4.25 / 2.62)) \times 100 \\
& =62.21 \%
\end{aligned}
$$

\section{Conclusion}

In this work, we have developed an electrode, bacteriapolymer-CPE. This electrode has shown acceptable activity for the electrochemical oxidation of phenol. The presence of the polymer on the surface of the organic matrices causes an increase in the porosity of the electrode surfaces, which facilitates the adsorption of the electroactive molecule. The polymer developed on the surface of the electrodes facilitates the adhesion and development of a biofilm on the surface. Bacteria-polymer-CPE electrode activity was tested for phenol oxidation. The presence of a biofilm incorporated in the organic matrix facilitates the degradation of the phenol. The methods used, in this case the cyclic and square wave voltammetries, the impedance diagrams, have allowed a global and efficient characterization of the elaborated electrodes.

\section{References}

1. Patty FA (1963) Industrial hygiene and toxicology Interscience 2: 1363.

2. Leithe W (1971) Analysis of air pollutants. Ann Arbor science. Ann Arbor MI P: 246.

3. Leithe W (1972) Analysis of organic pollutants in water and wastewater.
Ann Arbor science, Ann Arbor, MI: P:113.

4. Keith LH, Telliand WA (1979) ES \& T special priority pollutants. I A perspective view. Environmental Science Technology 13(4): 416-423.

5. Zhang F, Li M, Li WQ Feng CP, Guo YX (2011) Degradation of phenol by a combined independent photocatalytic and electrochemical process. Chemical Engineering Journal 175(1): 349-355.

6. Pauliukaite R, Brett C (2008) Poly (neutral red): Electrosynthesis characterization and application as a redox mediator. Electroanalysis 20(12): 1275-1285.

7. Pauliukaite R, Ghica ME, Barsan M, \& Brett CM (2007) Characterization of poly (neutral red) modified carbon film electrodes; application as a redox mediator for biosensors. J Solid State Electrochem 11(7): 899-908.

8. Hedenburg JF, Freiser H (1953) Anodic Voltammetry of Phenols. Anal Chem 25(9): 1355-1358.

9. MR Smyth, WF Voltammetric (1978) Methods for the determination of foreign organic compounds of biological significance. A review, Analyst 103(1227): 529.

10. Kalcher K (1990) Chemically modified carbon paste electrodes in voltammetric analysis. Electroanal 2(6): 419-433.

11. Gorton L (1995) Carbon paste electrodes modified with enzymes tissues and cells. Electroanal 7(1): 23-45.

12. Nematollahi D, Hesari M (2001) Electrochemical study of iodide in the presence of barbituric acid: Application to the catalytic determination of barbituric acid. J anal chem 56(12): 1109-1112.

13. Results properties of the laboratory of molecular electrochemistry and inorganic materials, Faculty of Science and Techniques of Beni Mellal.

14. Harouna Massai, Benguellah Benoitc, Mbadcam Joseph Ketcha, Abdelilah Chtaini (2009) Bulletin of the catalysis society of India. 2: 64-68.

15. Maallah R, Chtaini A (2018) Bacterial Electrode for the Oxidation and Detection of Phenol. Pharm Anal Acta 9(2): 580.

16. Maallah R, Moutcine A, Chtaini A (2016) Bioelectrochemical Systems for Clean Environment. J Biosens Bioelectron 7: 231. 